\title{
Enhancing Rice Productivity through Integration of Stress Tolerant Rice Varieties and Improved Nutrient Management Practices in Saline Areas of Bangladesh
}

\author{
M K A Bhuiyan ${ }^{1}$, A J Mridha ${ }^{1}$, S Singh², A K Srivastava², U S Singh², M A Bari ${ }^{3}$ and M A Ali ${ }^{4}$
}

\begin{abstract}
The study was conducted in two locations of coastal districts Patuakhali and Satkhira during 2012 and 2013 T. Aman season. Stress tolerant rice varieties along with nitrogen application using prilled urea (PU), leaf color chart (LCC), urea super granule (USG), and rice crop manager (RCM) software based nitrogen $(\mathrm{N})$ dose were examined. The objectives of the study were to identify the response of saline tolerant varieties to $\mathrm{N}$ fertilization on grain yield and profitability. Among the tested varieties, grain yield of BRRI dhan40, BRRI dhan41 and BRRI dhan54 were higher compared to BRRI dhan52 and BRRI dhan53 irrespective of location. There were no significant difference among the better performed varieties. Interaction effect of yield was significant in 2013 at Patuakhali but insignificant in both the locations in 2012. During 2013 in Patuakhali, the interaction effect of BRRI dhan40 $\times$ USG and BRRI dhan41 $\times$ USG produced higher grain yield and total $\mathrm{N}$ uptake. In Satkhira BRRI dhan54 and BRRI dhan 40 performed better and produced higher grain yield and $\mathrm{N}$ uptake. Among the $\mathrm{N}$ application treatments USG application was the best compared to either LCC or RCM. The combination of BRRI dhan54×USG and BRRI dhan41×USG had more economic gains in both 2012 and 2013 in Patuakhali. The combination of BRRI dhan52×USG and BRRI dhan41×LCC appeared as themost profitable in Satkhira during 2013. Integration of saline tolerant varieties along with USG application could improve the yield of saline tolerant rice in saline environment.
\end{abstract}

Key words: Saline tolerant rice varieties, Saline soil, nitrogen management

\section{INTRODUCTION}

About 400-950 million hectares (mha) of land around the world (Lin et al., 1998) is affected by different levels of salinity whereas about 0.83 mha land is affected by the salinity in Bangladesh (Karim et al., 1990). In addition, the coastal areas share about 25\% (2.5 mha) the total cropland in Bangladesh. Thus, soil salinity is the primary constraints toward the rice productivity in every rice growing country including Bangladesh. On the other hand, the imbalanced use of fertilizer and declining land productivity are the main concerns with the food insecurity in Bangladesh to feed the huge people (Uddin et al. ( 2011).
Salinity threatens both the plant root environment and hydrological situation and thereby devastating the normal crop production, but that varies across the crop seasons (Haque, 2006). The T. Aman rice is dominated by the low yield potential in Patuakhali. Notably, the average yield of $\mathrm{T}$. Aman rice in Bangladesh is nearly $3.75 \mathrm{t} \mathrm{ha}^{-1}$ (AIS, 2015). The cropping pattern T. AmanFallow-Fallow is the most prevalent in the coastal areas of both Patuakhali and Satkhira. In fact, these areas were given minor attention in the past. Most recently, it is an imperative to explore the possibilities of the saline affected lands to increase the food grain productions.

\footnotetext{
${ }^{1}$ Department of Agronomy, Bangladesh Rice Research Institute, Gazipur, Bangladesh, ${ }^{2}$ International Rice Research Institute, India office, New Delhi, India, ${ }^{3}$ International Rice Research Institute, Bangladesh office, Dhaka, Bangladesh, ${ }^{4}$ Director administration and common service, Bangladesh Rice Research Institute, Gazipur, Bangladesh. *Corresponding author's E-mail: bhuiyanbrri@gmail.com
} 
Salinity has a negligible impact due to the huge rainfall and upward flow of rivers when the crops are in the early phase of growth. In contrast, the soil salinity has an enormous effect on the later phase of crop due to the inadequacy of soil water at different soil profiles when the rain thoroughly stops. Moreover, soil salinity sometimes exceed the threshold limit of the tolerance of the rice crop. More certainly, salinity interrupts the plant growth and development and thereby causing the severe yield losses. Furthermore, the fertility level of most saline soils varies from low to very low according to the existence of the organic matter, nitrogen, phosphorus, and other micronutrients. That's why, proper doses of macro and micronutrients with the specific times are needed to meet up the nutrient requirements to boost up the crop productivity. It is also notable that traditional varieties, being very poor yielder are more commonly practiced in the saline areas. However, Bangladesh Rice Research Institute (BRRI) introduced the salt tolerant rice varieties. Among them, BRRI dhan 40 and BRRI dhan41 are more popular in Aman season in the coastal region (CCC, 2009). They can easily survive in the salinity range of 2 to $6 \mathrm{dS} \mathrm{m} \mathrm{m}^{-1}$ soil electrical conductivity (EC) until there productive stage. More recently, BRRI dhan53 and BRRI dhan54, high yielder accompanied by better grain quality and shorter duration, were released to combat in the salinity. But they can tolerate more salinity ranging from 7 to $8 \mathrm{dS} \mathrm{m}^{-1}$ in the reproductive phase (BRKB, 2017). The high salinity tremendously affects the rice growth and yield but the proper soil and fertilizers management can ensure the better production (Aslam et al. (1989). To be certain, combination of the aforesaid modern varieties and the improved nutrient management were proposed to examine the potentials of rice productivity in the saline areas since the farmers in the saline area did not use the modern genotype as well as the recommended fertilizers, more specifically nitrogenous fertilizers. Considering the current situation in the saline areas, this piece of research was undertaken to examine the performance of newly released salt tolerant varieties in the farmers' field with different nitrogen fertilizer source and method of application.

\section{MATERIALS AND METHODS}

Experimental site characterization. The onfarm experiments were conducted at two coastal saline districts- Patukhali and Sathkira. In Patuakhali, Pakhimara village under Kalapara Thana $\left(21^{\circ} 951829 \mathrm{~N}\right.$ latitude and $90^{\circ} 3748354 \mathrm{E}$ longitude, at an elevation of $0.65 \mathrm{~m} \mathrm{MSL}$ ), was selected and the experiments were conducted for the successive years during T. Aman 2012 and 2013. In 2013, an additional variety BRRI dhan52 and the nutrient recommendation from RCM of International Rice Research Institute were added. In Sathkira, Kulia village under Debhata Thana $\left(22^{\circ} 6426074 \mathrm{~N}\right.$ latitude and $88^{\circ} 9874502$ E longitude with an altitude of 3.5 $\mathrm{m}$ from mean sea level), was also selected as an experimental site for the experiment only during T. Aman, 2013 (Table 1). The major soil type of Patuakhali is non-calcareous loam with the ranges from 1.7 to $3.4 \%$ organic content and slightly acidic having the $\mathrm{pH}$ 6.57.0. The available $\mathrm{N}, \mathrm{P}$, and $\mathrm{K}$ are $0.1-0.2 \%$, 10-28 ppm, 0.2-0.6 meq\%, respectively. The region is characterized by a close network of inter connected tidal rivers and creeks. The whole region of Patuakhali is lying within the cyclone zone and Satkhira lying in the Gangetic tidal floodplains. The main soil types are noncalcareous and clay loam having 1.8-2.2\% organic matter and $6.2-8.4 \mathrm{pH}$. The available $\mathrm{N}, \mathrm{P}$ and $\mathrm{K}$ are $0.1-0.3 \%, 12-24$ ppm, 0.2-1.2 $\mathrm{meq} \%$, respectively. Maximum and minimum temperature, rainfall data were collected from the meteorological department and presented in (Fig. 1).

Experimental design and management. Table 1 presents the experimental treatments. The experiments were conducted in the split plot design where the varieties were used in the main plots and $\mathrm{N}$-managements applied in the sub plots. In both the experimental locations during 2013, BRRI dhan52 and the crop nutrient 
Table 1. Details of on-farm experiment conducted at Patuakhali in 2012 and 2013 and Sathkira in 2013 during T. Aman season.

\begin{tabular}{|c|c|c|}
\hline Experimental site & Patuakhali & Patuakhali and Satkhira \\
\hline \multirow{5}{*}{ Variety } & BRRI dhan 40 & BRRI dhan 40 \\
\hline & BRRI dhan 41 & BRRI dhan 41 \\
\hline & BRRI dhan53 & BRRI dhan52 \\
\hline & BRRI dhan54 & BRRI dhan53 \\
\hline & - & BRRI dhan54 \\
\hline \multirow{4}{*}{$\mathrm{N}$ management } & PU & PU \\
\hline & LCC & LCC \\
\hline & USG & USG \\
\hline & - & $\mathrm{RCM}$ \\
\hline \multicolumn{3}{|l|}{ Fertilizer rate $\left(\mathrm{kg} \mathrm{ha}^{-1}\right)$} \\
\hline TSP-MoP-ZnSO ${ }_{4} \cdot \mathrm{H}_{2} \mathrm{O}$-gypsum & $100-120-7.5-68$ & $100-120-7.5-68$ \\
\hline LCC-N & 52 & 52 \\
\hline USG (1.8 g)-N & 50 & 50 \\
\hline PU-N & 69 & 69 \\
\hline
\end{tabular}

TSP: Triple Super Phosphate, MoP: Muriate of Potash, PU: Prilled Urea, LCC: Leaf Colour Chart, USG: Urea Super Granule, RCM: Rice crop manager.
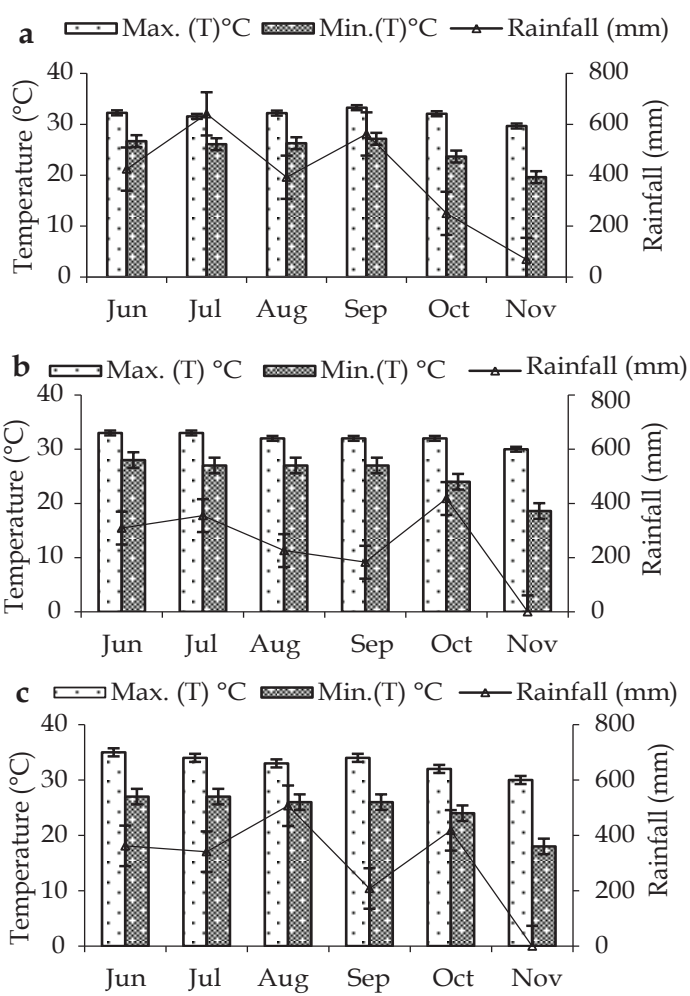

Fig. 1. Monthly average maximum and minimum temparature $\left({ }^{\circ} \mathrm{C}\right)$ and total rainfall of Kalapara, Patuakhali district during (a) June 2012 to November 2012, (b) June 2013 to November 2013 and (c) Satkhira district during June 2013 to November 2013. manager were also used. Tables 2 and 3 present details of crop nutrient manager. Nitrogen doses were recommended as 69,52 , and $50 \mathrm{~kg}$ ha $^{-1}$ from PU, LCC, and USG respectively. The unit plot size was $5 \times 6 \mathrm{~m}^{2}$ with $20 \times 15 \mathrm{~cm}$ row to row spacing and three farmers' plots were taken for three replications. BRRI recommended technology packages were followed in order to raise the seedlings and other intercultural operations. The fertilizer package 100-120$68-7.5 \mathrm{~kg} \mathrm{ha}^{-1}$ that corresponds to triple super phosphate, muriate of potash, gypsum, and zinc sulphate were applied as basal following BRRI recommendation. In addition, PU was applied in three equal splits at 15 days after transplanting (DAT), maximum tillering and panicle initiation stage. LCC reading was recorded and urea was applied two times accordingly. USG (1.8g) was applied at 10 DAT in the middle of the alternate four hills. The 35-day-old seedlings was transplanted on $4^{\text {th }}$ August 2012 in Patuakhali, whereas transplanted on $1^{\text {st }}$ and $6^{\text {th }}$ August, 2013 in Patuakhali and Satkhira site respectively. Simultaneously, water salinity was recorded at every seven days interval. The standard recommended plant protection measures were adopted to ensure the uninterrupted crop growth. 
Table 2. Details of on-farm RCM treatment conducted at Kalapara, Patuakhali during T. Aman 2013.

\begin{tabular}{|c|c|c|c|c|}
\hline \multirow{2}{*}{ Variety and growth stage } & \multirow{2}{*}{ Date of application } & \multicolumn{3}{|c|}{ Fertilizer for 33 decimals (kg) } \\
\hline & & TSP & MOP & Urea \\
\hline \multicolumn{5}{|c|}{ BRRI dhan 40} \\
\hline Basal & 0 & 4 & 2 & - \\
\hline Early & Aug 14-18 & - & - & 7 \\
\hline Active tillering & Sept 6-10 & - & - & 8 \\
\hline Panicle initiation & Sept $22-26$ & - & - & 8 \\
\hline \multicolumn{5}{|c|}{ BRRI dhan 41} \\
\hline Basal & 0 & 4 & 2 & - \\
\hline Early & Aug 14-18 & - & - & 7 \\
\hline Active tillering & Sept $11-15$ & - & - & 8 \\
\hline Panicle initiation & Sept $27-31$ & - & - & 8 \\
\hline \multicolumn{5}{|c|}{ BRRI dhan52 } \\
\hline Basal & 0 & 4 & 2 & - \\
\hline Early & Aug 14-18 & - & - & 7 \\
\hline Active tillering & Sept 6-10 & - & - & 8 \\
\hline Panicle initiation & Sept 22-26 & - & - & 8 \\
\hline \multicolumn{5}{|c|}{ BRRI dhan 53} \\
\hline Basal & 0 & 3 & 4 & - \\
\hline Early & Aug 14-18 & - & - & 7 \\
\hline Active tillering & Aug 24-28 & - & - & - \\
\hline Panicle initiation & Sept 2-6 & - & - & 10 \\
\hline \multicolumn{5}{|c|}{ BRRI dhan54 } \\
\hline Basal & 0 & 4 & 2 & - \\
\hline Early & Aug 14-18 & - & - & 7 \\
\hline Active tillering & Aug 27-31 & - & - & 8 \\
\hline Panicle initiation & Sept $12-16$ & - & - & 8 \\
\hline
\end{tabular}

Data collection and statistical analysis. Data on yield and yield character were calculated according to Gomez K A (1972). Straw and grain samples were stored for $\mathrm{N}$ content estimation. The samples were oven dried at $70^{\circ} \mathrm{C}$ for 72 hours, weighed, ground, and then subsamples were taken for $\mathrm{N}$ determination. The $\mathrm{N}$ content in straw and grains was measured by the standard microKjeldahl procedure (Bremner and Mulvaney, 1982). The N-uptake in grain and straw was calculated by following formulae.
Finally, the collected data were analyzed with software CROPSTAT 7.2. The least significant difference (LSD) at 5\% probability was used to compare the means of the treatments (Gomez and Gomez, 1984).

Economic analysis. Economic comparison of the treatments were checked based on the production cost, gross return, net return, and benefit-cost ratio (BCR). The total variable cost was calculated by the inputcosts (seeds, fertilizers and pesticides); costs of human labour for land preparation, irrigation,

Nitrogen uptake by grain $\left(\mathrm{kg} \mathrm{ha}^{-1}\right)=\frac{\% \mathrm{~N} \text { in grain } \times \text { grain yield }\left(\mathrm{kg} \mathrm{ha}^{-1}\right)}{100}$

Nitrogen uptake by straw $\left(\mathrm{kg} \mathrm{ha}^{-1}\right)=\frac{\% \mathrm{~N} \text { in straw } \times \text { straw yield }\left(\mathrm{kg} \mathrm{ha}^{-1}\right)}{100}$ 
Table 3. Details of on-farm RCM treatment conducted at Debhata, Satkhira during T. Aman 2013.

\begin{tabular}{|c|c|c|c|c|c|}
\hline \multirow{2}{*}{ Variety and growth stage } & \multirow{2}{*}{ Date of application } & \multicolumn{4}{|c|}{ Fertilizer for 33 decimals $(\mathrm{kg})$} \\
\hline & & TSP & MOP & Urea & Zinc sulphate \\
\hline \multicolumn{6}{|c|}{ BRRI dhan 40} \\
\hline Basal & 0 & 4 & 2 & 0 & 0.7 \\
\hline Early & Aug 14-18 & - & - & 7 & - \\
\hline Active tillering & Sept 6-10 & - & - & 8 & - \\
\hline Panicle initiation & Sept 22-26 & - & - & 8 & - \\
\hline \multicolumn{6}{|c|}{ BRRI dhan 41} \\
\hline Basal & 0 & 4 & 2 & - & 0.7 \\
\hline Early & Aug 14-18 & - & - & 7 & - \\
\hline Active tillering & Sept 11-15 & - & - & 8 & - \\
\hline Panicle initiation & $\begin{array}{l}\text { Sept 27-31 } \\
\text { BRRI dhan52 }\end{array}$ & - & - & 8 & - \\
\hline Basal & 0 & 4 & 2 & - & 0.7 \\
\hline Early & Aug 14-18 & - & - & 7 & - \\
\hline Active tillering & Sept $16-20$ & - & - & 8 & - \\
\hline Panicle initiation & $\begin{array}{l}\text { Oct } 1-5 \\
\text { BRRI dhan } 53\end{array}$ & - & - & 8 & - \\
\hline Basal & 0 & 4 & 4 & - & - \\
\hline Early & Aug14-18 & - & - & 9 & - \\
\hline Active tillering & Aug 24-27 & - & - & & - \\
\hline Panicle initiation & $\begin{array}{l}\text { Sept 2-6 } \\
\text { BRRI dhan54 }\end{array}$ & - & - & 12 & - \\
\hline Basal & 0 & 4 & 2 & - & 0.7 \\
\hline Early & Aug 14-18 & - & - & 7 & - \\
\hline Active tillering & Aug 27-31 & - & - & 8 & - \\
\hline Panicle initiation & Sept $12-16$ & - & - & 8 & - \\
\hline
\end{tabular}

fertilizer, pesticide applications, harvesting, bundling, carrying, and threshingthe rent of a power tiller and irrigation cost. Gross return was calculated by multiplying the quantity of production (grain and straw) by the output price at the harvest time. The net return and BCR were computed as follows:

Net return =Gross return-cost of production, $\mathrm{BCR}=$ Gross return / cost of production .

The economic analysis was conducted by taking into account the prevailing market price of inputs, labours and produce during the year 2012-13 in Bangladeshi Taka (BDT) and then converted into US\$ using the conversion rate $1 \mathrm{US} \$=78 \mathrm{BDT}$.

\section{RESULTS AND DISCUSSION}

Effect of water salinity. The on-farm field crop result showed that all the newly developed saline tolerant varieties grew very well as there wasa little salinity impact on crop production due to the better rainfall throughout the experiment period (Fig. 1). In both Pakhimara of Patuakhali, and Kulia of Satkhira, the fluctuation of soil salinity throughout the onfarm crop growing season was documented at weekly interval (Fig. 2). In Patuakhali during 2012 and 2013, water salinity varied from 1.39 to 2.87 and 1.30 to $2.32 \mathrm{dS} \mathrm{m}^{-1}$ respectively. In Satkhira, water salinity varied from 0.32 to 1.32 $\mathrm{dS} \mathrm{m}^{-1}$ in the experimental plot for the same season. In Patuakali's on-farm experimental site, the salinity level was higher than that of Satkhira. However, the low intent of soil salinity did not cause any detrimental effect on the crop development and productivity atboth the experimental sites.

Yield attributing characters, yield and nitrogen uptake at Patuakhali in 2012 and 2013. Table 4 presents plant height at maturity, yield attributes and grain yield during 2012 at Patuakhali. Crop performance showed that in 

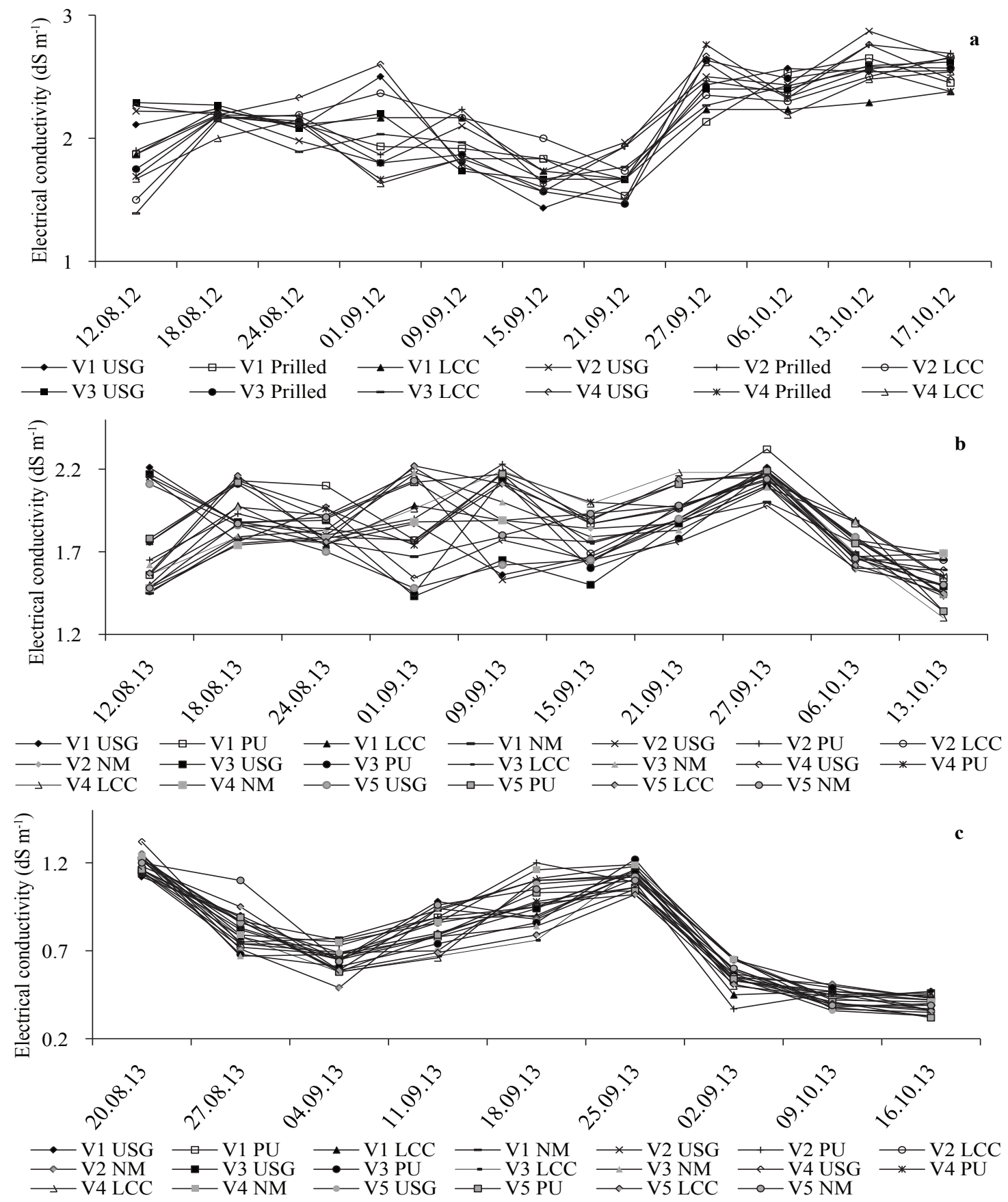

V1: BRRI dhan40, V2: BRRI dhan41, V3: BRRI dhan53, V4: BRRI dhan54, V5: BRRI dhan52; PU: Prilled urea, LCC: Leaf colour chart, USG: Urea super granule, NM: Nutrient manager (RCM) V5 and NM was introduced during 2013 at Patuakhali and Satkhira.

Fig. 2. Weekly fluctuation of salinity at farmers' field a). and b). Pakhimara, Patuakhali during T. Aman 2012 and 2013, respectively; and c). Kulia, Satkhira during T. Aman 2013. 
Table 4. Plant height, yield attributing characters and grain yield in different salt tolerant varieties, influenced by $\mathrm{N}$ management at Kalapara, Patuakhali during T. Aman 2012.

\begin{tabular}{|c|c|c|c|c|c|c|}
\hline Treatment & $\begin{array}{l}\text { Plant height } \\
\quad(\mathrm{cm})\end{array}$ & Panicle $\mathrm{m}^{-2}$ & $\begin{array}{c}\text { Grain } \\
\text { panicle }^{-1}\end{array}$ & $\begin{array}{c}1000 \text { grain } \\
\text { wt (g) }\end{array}$ & $\begin{array}{c}\text { Panicle length } \\
(\mathrm{cm})\end{array}$ & $\begin{array}{l}\text { Grain yield } \\
\quad\left(\mathrm{t} \mathrm{ha}^{-1}\right)\end{array}$ \\
\hline \multicolumn{7}{|c|}{ Variety } \\
\hline BRRI dhan 40 & 109.6 & 196.00 & 78 & 24.72 & 24.93 & 4.16 \\
\hline BRRI dhan 41 & 113.14 & 191.67 & 74 & 25.31 & 25.27 & 4.09 \\
\hline BRRI dhan 53 & 108.25 & 164.22 & 63 & 23.53 & 21.68 & 3.57 \\
\hline BRRI dhan54 & 102.11 & 185.44 & 81 & 25.32 & 24.48 & 4.29 \\
\hline $\mathrm{LSD}_{0.05}$ & 5.64 & ${ }^{\mathrm{a}} \mathrm{ns}$ & 10.6 & 0.68 & 1.19 & 0.40 \\
\hline \multicolumn{7}{|c|}{$N$ management } \\
\hline USG & 107.87 & 193.53 & 78 & 25.01 & 24.37 & 4.22 \\
\hline PU & 108.41 & 180.58 & 72 & 24.53 & 23.83 & 3.94 \\
\hline LCC & 108.57 & 178.83 & 72 & 24.62 & 24.08 & 3.92 \\
\hline $\mathrm{LSD}_{0.05}$ & ns & ns & ns & ns & ns & ns \\
\hline
\end{tabular}

ns: not significant, PU: Prilled urea, LCC: Leaf colour chart, USG: Urea super granule.

the main plot, plant height at harvest of different varieties differed significantly whereas nitrogen management had no significant influence on the plant height of varieties. There was no significant effect of panicle $\mathrm{m}^{-2}$ in main plot and sub plots, although in main plot, BRRI dhan 40 produced higher panicles $\mathrm{m}^{-2}$ (196) and in sub plot USG treated plots produced higher panicles $\mathrm{m}^{-2}$ (193). Grains panicle ${ }^{-1}, 1000$ grain weight (TGW) and panicle length of the varieties differed significantly in the main plot but significant difference in sub plot ( $\mathrm{N}$ management). The highest grains panicle $\mathrm{e}^{-1}$ in main plot was observed in BRRI dhan 40 closely followed by BRRI dhan 54 and the lowest was produced from BRRI dhan53. Grain weight (1000-seed) was the highest in BRRI dhan54 followed by BRRI dhan41 and the lowest was observed from BRRI dhan53. Length of panicle varied significantly in both varieties and nitrogen management. Regarding main effects of varieties, the highest grain yield was observed in BRRI dhan54 (4.29 $\left.\mathrm{t} \mathrm{ha}^{-1}\right)$ and the lowest yield (3.57 $\mathrm{t} \mathrm{ha}^{-1}$ ) in BRRI dhan53. Regarding $\mathrm{N}$ management treatment, USG produced the highest grain yield $\left(4.22 \mathrm{t} \mathrm{ha}^{-1}\right)$ followed by prilled urea (3.94 $\left.\mathrm{t} \mathrm{ha}^{-1}\right)$. The lowest grain yield $\left(3.92 \mathrm{t} \mathrm{ha}^{-1}\right)$ was recorded from LCC treatment.

Table 5 presents varietal effect and nitrogen management on nitrogen uptake in grain and straw. Varieties and nitrogen management differed significantly on grain and straw nitrogen uptake. In the main plot, nitrogen uptake in grain (25.96 $\left.\mathrm{kg} \mathrm{ha}^{-1}\right)$ and straw (11.40 $\mathrm{kg} \mathrm{ha}^{-1}$ ) was found the highest in BRRI dhan41 and in sub plot $\mathrm{N}$ applied through USG (27.43 $\mathrm{kg} \mathrm{ha}^{-1}$ in grain and $11.81 \mathrm{~kg} \mathrm{ha}^{-1}$ in straw). The lowest nitrogen uptake, in grain and straw, was found in BRRI dhan53 and $\mathrm{N}$ management through LCC treatment. Grain yield was found significantly and linearly related with total $\mathrm{N}$ uptake (Fig. 3a) indicating that higher grain yield would be due to higher $\mathrm{N}$ uptake. Kabir et al. (2011) observed variation in $\mathrm{N}$ uptake by grain was 25.14 to $48.02 \mathrm{~kg} \mathrm{ha}^{-1}$ at Satkhira district, Bangladesh in STL-655 rice mutant cultivar. Similarly, the range of $\mathrm{N}$ uptake by straw was 20.36 to $35.85 \mathrm{~kg} \mathrm{ha}^{-1}$.

Table 6 presents plant height at maturity, yield and yield attributing characters. In 2013 at Patuakhali crop performance showed that plant height at harvest differed significantly in main plot, but in nitrogen management plot (sub plot) did not influenced significantly. There were no significant effect on panicle $\mathrm{m}^{-2}$, grain panicle ${ }^{-1}$ and TGW of the varieties in main plot; but in sub plot, nitrogen management significantly affected on panicle $\mathrm{m}^{-2}$, grain panicle $\mathrm{e}^{-1}$ and TGW. Length of panicles varied significantly 
Table 5. Nitrogen uptake in grain and straw of different salt tolerant varieties, influenced by $\mathrm{N}$ management at Kalapara, Patuakhali during T. Aman 2012.

\begin{tabular}{|c|c|c|}
\hline \multirow[t]{2}{*}{ Treatment } & \multicolumn{2}{|c|}{$\mathrm{N}$ uptake $\left(\mathrm{kg} \mathrm{ha}^{-1}\right)$} \\
\hline & Grain & Straw \\
\hline \multicolumn{3}{|c|}{ Variety } \\
\hline BRRI dhan 40 & 25.96 & 11.40 \\
\hline BRRI dhan41 & 24.77 & 10.77 \\
\hline BRRI dhan53 & 21.41 & 8.75 \\
\hline BRRI dhan54 & 27.04 & 11.91 \\
\hline $\mathrm{LSD}_{0.05}$ & 2.66 & 1.64 \\
\hline \multicolumn{3}{|c|}{$N$ management } \\
\hline USG & 27.43 & 11.81 \\
\hline PU & 23.51 & 10.08 \\
\hline LCC & 23.45 & 10.24 \\
\hline $\mathrm{LSD}_{0.05}$ & 1.90 & 1.01 \\
\hline
\end{tabular}

PU: Prilled urea, LCC: Leaf colour chart, USG: Urea super granule.

both in varieties and nitrogen management. Regarding main effects of varieties, the highest grain yield was recorded in BRRI dhan40 (4.53 $\left.\mathrm{t} \mathrm{ha} \mathrm{a}^{-1}\right)$ and the lowest yield (2.88 $\left.\mathrm{t} \mathrm{ha}^{-1}\right)$ was recorded in BRRI dhan53. Regarding nitrogen management treatment, USG produced the highest grain yield $\left(5.03 \mathrm{t} \mathrm{ha}^{-1}\right)$ followed by
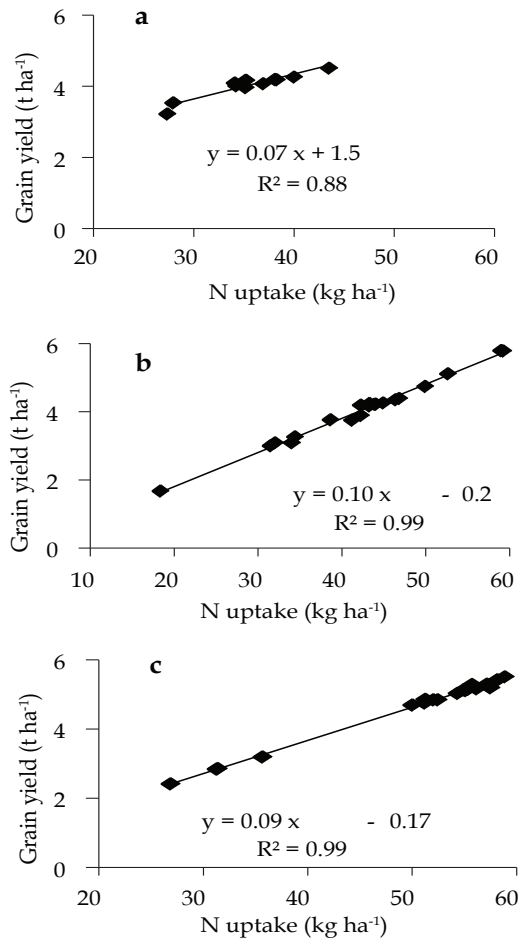

Fig. 3. Relationship among grain yield and $\mathrm{N}$ uptake in salt tolerant varieties at a). and b). Patuakhali during T. Aman 2012 and 2013 respectively; and c) Satkhira during T. Aman 2013.

Table 6. Plant height, yield and yield attributing characters of different salt tolerant varieties, influenced by $\mathrm{N}$ management at Kalapara, Patuakhali during T. Aman 2013.

\begin{tabular}{|c|c|c|c|c|c|c|}
\hline Treatment & $\begin{array}{l}\text { Plant height } \\
\text { (cm) }\end{array}$ & Panicle $\mathrm{m}^{-2}$ & $\begin{array}{l}\text { Grains } \\
\text { panicle }^{-1}\end{array}$ & $\begin{array}{l}1000 \text { grain } \\
\mathrm{wt}(\mathrm{g})\end{array}$ & $\begin{array}{c}\text { Panicle length } \\
\text { (cm) }\end{array}$ & Grain yield $\left(t \mathrm{tha}^{-1}\right)$ \\
\hline \multicolumn{7}{|c|}{ Variety } \\
\hline BRRI dhan40 & 112.35 & 176.08 & 71 & 25.98 & 25.86 & 4.53 \\
\hline BRRI dhan41 & 115.91 & 172.83 & 77 & 25.86 & 26.31 & 4.36 \\
\hline BRRI dhan53 & 104.80 & 136.58 & 62 & 26.02 & 21.28 & 2.88 \\
\hline BRRI dhan54 & 100.58 & 164.83 & 71 & 25.57 & 21.68 & 4.30 \\
\hline BRRI dhan52 & 108.15 & 164.58 & 71 & 25.65 & 21.17 & 4.17 \\
\hline $\mathrm{LSD}_{0.05}$ & 7.64 & ns & ns & ns & 2.21 & 0.74 \\
\hline \multicolumn{7}{|c|}{$N$ management } \\
\hline USG & 107.90 & 175.93 & 81.35 & 27.03 & 24.89 & 5.03 \\
\hline PU & 109.26 & 167.93 & 71.47 & 25.92 & 23.18 & 4.04 \\
\hline LCC & 109.37 & 160.80 & 71.22 & 25.30 & 22.80 & 3.98 \\
\hline $\mathrm{RCM}$ & 106.93 & 147.26 & 58.08 & 25.01 & 22.17 & 3.13 \\
\hline $\mathrm{LSD}_{0.05}$ & ns & 12.43 & 5.80 & 0.98 & 1.23 & 0.28 \\
\hline
\end{tabular}

ns: not significant, PU: Prilled urea, LCC: Leaf colour chart, USG: Urea super granule, RCM: Rice crop manager. 
prilled urea $\left(4.04 \mathrm{t} \mathrm{ha}^{-1}\right)$. The lowest grain yield $\left(3.13 \mathrm{t} \mathrm{ha}^{-1}\right)$ was observed in nutrient manager treatment. Interaction effect of varieties and nitrogen management differed significantly on grain yield and nitrogen uptake (Table 7). BRRI dhan $41 \times$ USG produced the highest grain yield $\left(5.79 \mathrm{t} \mathrm{ha}^{-1}\right)$ which was statistically similar with the BRRI dhan $40 \times$ USG $\left(5.78 \mathrm{tha}^{-1}\right)$. The lowest grain yield $\left(1.67 \mathrm{t} \mathrm{ha}^{-1}\right)$ was recorded from BRRI dhan53 $\times$ nutrient manager treatment. The highest nitrogen uptake in grain was observed in BRRI dhan $41 \times$ USG treatment $\left(59.21 \mathrm{~kg} \mathrm{ha}^{-1}\right)$ followed by BRRI dhan $40 \times$ USG $\left(58.96 \mathrm{~kg} \mathrm{ha}^{-1}\right)$. The lowest nitrogen uptake in grain was from BRRI dhan53 $\times$ nutrient manager treatment

Table 7. Interaction effect of salt tolerant varieties and $\mathrm{N}$ management on grain yield and grain $\mathrm{N}$ uptake at Kalapara, Patuakhali during T. Aman 2013.

\begin{tabular}{|c|c|c|}
\hline $\mathrm{N}$ management $(\mathrm{NM})$ & $\begin{array}{l}\text { Grain yield } \\
\qquad\left(\mathrm{t} \mathrm{ha} \mathrm{a}^{-1}\right)\end{array}$ & $\begin{array}{l}\text { Grain N uptake } \\
\qquad\left(\mathrm{kg} \mathrm{ha}^{-1}\right)\end{array}$ \\
\hline \multicolumn{3}{|c|}{ BRRI dhan 40} \\
\hline USG & 5.78 & 41.87 \\
\hline PU & 4.39 & 31.90 \\
\hline LCC & 4.19 & 29.92 \\
\hline $\mathrm{RCM}$ & 3.75 & 27.95 \\
\hline \multicolumn{3}{|c|}{ BRRI dhan 41} \\
\hline USG & 5.79 & 42.67 \\
\hline PU & 4.24 & 30.83 \\
\hline LCC & 4.17 & 30.13 \\
\hline $\mathrm{RCM}$ & 3.26 & 23.71 \\
\hline \multicolumn{3}{|c|}{ BRRI dhan 53} \\
\hline USG & 3.76 & 26.99 \\
\hline PU & 3.00 & 21.62 \\
\hline LCC & 3.09 & 22.28 \\
\hline $\mathrm{RCM}$ & 1.67 & 12.33 \\
\hline \multicolumn{3}{|c|}{ BRRI dhan54 } \\
\hline USG & 4.74 & 34.16 \\
\hline PU & 4.35 & 31.95 \\
\hline LCC & 4.22 & 30.12 \\
\hline $\mathrm{RCM}$ & 3.89 & 29.31 \\
\hline \multicolumn{3}{|c|}{ BRRI dhan52 } \\
\hline USG & 5.11 & 36.72 \\
\hline PU & 4.22 & 30.93 \\
\hline LCC & 4.26 & 30.87 \\
\hline $\mathrm{RCM}$ & 3.09 & 22.94 \\
\hline $\mathrm{LSD}_{0.05}$ & 0.74 & 5.27 \\
\hline $\mathrm{RCM}$ & 0.28 & 2.09 \\
\hline $\mathrm{V} \times \mathrm{RCM}$ & 0.62 & 4.67 \\
\hline
\end{tabular}

PU: prilled urea, LCC: Leaf colour chart, USG: Urea super granule, RCM: Rcie crop manager. $\left(18.37 \mathrm{~kg} \mathrm{ha}^{-1}\right)$. Nitrogen uptake in grain + straw was highest in BRRI dhan $40 \times$ USG followed by BRRI dhan41 × USG treatment. Rice varieties varied in yield responses to applied nitrogen, have been reported by Fageria and Barbosa Filho (2001), Fageria and Baligar (2005). Similarly, genotypic variations in $\mathrm{N}$ uptake and utilization have been reported by Fageria and Baligar, (2005).

Yield attributing characters, yield and nitrogen uptake at Satkhira in 2013. Table 8 presents plant height at maturity, yield and yield attributes of rice varieties, and nitrogen management at Satkhira district during 2013. Varieties differed significantly regarding plant height, panicle $\mathrm{m}^{-2}$, panicle length and grain yield. TGW was not differed significantly in main plot. The highest plant height was observed in BRRI dhan41 and the lowest was in BRRI dhan54. The highest panicles $\mathrm{m}^{-2}$ (219) was produced from BRRI dhan54 followed by BRRI dhan40. The lowest panicle was produced in BRRI dhan53. The highest grains panicle ${ }^{-1}$ (86) was observed in BRRI dhan54 followed by BRRI dhan40 (85) and the lowest (63) was observed in BRRI dhan53. The highest panicle length $(\mathrm{cm})$ was observed in BRRI dhan41 $(26.15 \mathrm{~cm})$ followed by BRRI dhan $40(26.10 \mathrm{~cm})$. The lowest panicle length was recorded from BRRI dhan52 (22.48). Higher yield attributing characters lead to achieve highest grain yield in BRRI dhan54 (5.22 $\mathrm{t} \mathrm{ha}^{-1}$ ) followed by BRRI dhan41 (5.18 $\mathrm{t} \mathrm{ha}^{-1}$ ) (Table 8). Nitrogen management differed significantly on yield attributing characters. The highest panicles $\mathrm{m}^{-2}$, grains panicle ${ }^{-1}$, panicle length and TGW were observed in USG treatment irrespective of variety, which lead to produce highest grain yield (4.96 $\mathrm{t} \mathrm{ha}^{-1}$ ) followed by prilled urea. The lowest grain yield was produced from nutrient manager treatment (4.41 $\left.\mathrm{t} \mathrm{ha}^{-1}\right)$. $\mathrm{N}$ uptake in grain and straw differed significantly (Table 9). The highest $\mathrm{N}$ uptake in grain was recorded in BRRI dhan 40 followed by BRRI dhan 54 and the lowest in BRRI dhan53. Nitrogen uptake in grain and straw due to nitrogen management were not differed significantly. Islam et al. (2011) observed that in T. Aman season, plant 
Table 8. Plant height and yield attributing characters of different salt tolerant varieties, influenced by $\mathbf{N}$ management at Debhata, Satkhira during T. Aman 2013.

\begin{tabular}{|c|c|c|c|c|c|c|}
\hline Treatment & $\begin{array}{l}\text { Plant height } \\
(\mathrm{cm})\end{array}$ & Panicle $\mathrm{m}^{-2}$ & Grain panicle $^{-1}$ & $\begin{array}{c}1000 \text { grain } \\
\text { wt (g) }\end{array}$ & $\begin{array}{l}\text { Panicle length } \\
(\mathrm{cm})\end{array}$ & $\begin{array}{l}\text { Grain yield } \\
\left(\mathrm{t} \mathrm{ha}^{-1}\right)\end{array}$ \\
\hline \multicolumn{7}{|c|}{ Variety } \\
\hline BRRI dhan 40 & 113.29 & 218.33 & 85.33 & 26.34 & 26.10 & 5.18 \\
\hline BRRI dhan41 & 116.00 & 207.41 & 79.16 & 26.67 & 26.15 & 4.97 \\
\hline BRRI dhan53 & 108.33 & 176.33 & 63.08 & 24.95 & 23.29 & 2.82 \\
\hline BRRI dhan54 & 104.32 & 219.75 & 85.83 & 24.72 & 23.38 & 5.22 \\
\hline BRRI dhan52 & 108.77 & 217.16 & 77.58 & 24.92 & 22.48 & 5.03 \\
\hline $\mathrm{LSD}_{0.05}$ & 5.85 & 21.69 & 6.16 & ns & 0.96 & 0.26 \\
\hline \multicolumn{7}{|c|}{$N$ management } \\
\hline USG & 110.38 & 220.13 & 84.20 & 26.29 & 25.38 & 4.96 \\
\hline PU & 110.73 & 209.93 & 79.53 & 25.65 & 24.57 & 4.65 \\
\hline LCC & 110.71 & 206.20 & 75.73 & 25.25 & 23.96 & 4.57 \\
\hline $\mathrm{RCM}$ & 108.75 & 194.93 & 73.33 & 24.88 & 23.21 & 4.41 \\
\hline $\mathrm{LSD}_{0.05}$ & ns & 11.89 & 4.58 & 0.75 & 1.17 & 0.32 \\
\hline
\end{tabular}

PU: Prilled urea, LCC: Leaf colour chart, USG: Urea super granule, RCM: Rice crop manager, ns: not significant.

Table 9. Nitrogen uptake in grain and straw of different salt tolerant varieties, influenced by $\mathrm{N}$ management at Debhata, Satkhira during T. Aman 2013.

\begin{tabular}{|c|c|c|}
\hline \multirow[t]{2}{*}{ Treatment } & \multicolumn{2}{|c|}{$\mathrm{N}$ uptake (kg ha-1) } \\
\hline & Grain & Straw \\
\hline \multicolumn{3}{|c|}{ Variety } \\
\hline BRRI dhan 40 & 40.30 & 15.65 \\
\hline BRRI dhan41 & 37.82 & 15.23 \\
\hline BRRI dhan53 & 21.65 & 9.66 \\
\hline BRRI dhan54 & 39.06 & 17.28 \\
\hline BRRI dhan52 & 37.65 & 16.57 \\
\hline $\mathrm{LSD}_{0.05}$ & 2.84 & 1.35 \\
\hline \multicolumn{3}{|c|}{$N$ management } \\
\hline USG & 37.46 & 15.82 \\
\hline PU & 35.26 & 14.94 \\
\hline LCC & 35.21 & 14.53 \\
\hline $\mathrm{RCM}$ & 33.25 & 14.23 \\
\hline $\mathrm{LSD}_{0.05}$ & ns & ns \\
\hline
\end{tabular}

PU: Prilled urea, LCC: Leaf colour chart, USG: Urea super granule, RCM: Rice crop manager, ns: not significant.

height, number of tillers, total dry matter (TDM), length of panicles, number of filled grains, TGW and grain yield were gradually decreased with the increase level of salinity.
Sharma et al., 2013 recommended that BRRI dhan40, BRRI dhan41, BRRI dhan51, BRRI dhan52, BRRI dhan53 and BRRI dhan54 are suitable for cultivation in T. Aman season to improve the productivity of southern coastal region of Bangladesh where salinity level are low. Genotypic variation in grain yield, straw yield and nitrogen uptake by grain and straw were also reported by Saleque et al. (2004).

Economic analysis. The production cost was calculated based on the prices in local market of Patuakali and Satkhira during T. Aman, 2012 and 2013. A total of US\$ 660 and $703 \mathrm{ha}^{-1}$ was an average cost of rice production during 2012 and 2013 in Patuakhali and Satkhira respectively. Treatment dependent costs of cultivation were calculated on the basis of the additional inputs needed (Tables 10, 11 and 12). The BRRI dhan54 $\times$ USG showed the highest benefit cost ratio (BCR; 1.78) (Table 10). The calculated BCR showed that all treatment combinations had a BCR above 1.5 except BRRI dhan54 × LCC (1.29) and BRRI dhan53 $\times$ LCC (1.36). A BCR more than 2 appears to be good investment that yields a double return per unit investment (Reddy and Reddy, 
Table 10. Economic analyses (US $\$ \mathrm{ha}^{-1}$ ) of cost and return of $\mathrm{N}$ management with new salt tolerant varieties in onfarm studies at Kalapara, Patuakhali during T. Aman 2012.

\begin{tabular}{|c|c|c|c|c|}
\hline Treatment & $\begin{array}{c}\text { Cost of } \\
\text { cultivation }\end{array}$ & $\begin{array}{l}\text { Gross } \\
\text { return }\end{array}$ & $\begin{array}{l}\text { Net } \\
\text { return }\end{array}$ & $\mathrm{BCR}$ \\
\hline BRRI dhan $40 \times$ PU & 724 & 1144 & 421 & 1.58 \\
\hline BRRI dhan41 × PU & 724 & 1163 & 440 & 1.61 \\
\hline BRRI dhan53 × PU & 724 & 1168 & 444 & 1.61 \\
\hline BRRI dhan 54 × PU & 724 & 1124 & 400 & 1.55 \\
\hline BRRI dhan $40 \times$ LCC & 722 & 1147 & 425 & 1.59 \\
\hline BRRI dhan $41 \times$ LCC & 722 & 1163 & 441 & 1.61 \\
\hline BRRI dhan $53 \times$ LCC & 722 & 982 & 261 & 1.36 \\
\hline BRRI dhan $54 \times$ LCC & 722 & 929 & 207 & 1.29 \\
\hline BRRI dhan $40 \times$ USG & 705 & 1117 & 412 & 1.58 \\
\hline BRRI dhan $41 \times$ USG & 705 & 1160 & 454 & 1.64 \\
\hline BRRI dhan 53 × USG & 705 & 1168 & 463 & 1.66 \\
\hline BRRI dhan 54 × USG & 705 & 1257 & 552 & 1.78 \\
\hline
\end{tabular}

PU: Prilled urea, LCC: Leaf colour chart, USG: Urea super granule.

Table 11. Economic analyses (US $\$ \mathrm{ha}^{-1}$ ) of cost and return of $\mathrm{N}$ management with new salt tolerant varieties in onfarm studies at Kalapara, Patuakhali during T. Aman 2013.

\begin{tabular}{|c|c|c|c|c|}
\hline Treatment & $\begin{array}{c}\text { Cost of } \\
\text { cultivation }\end{array}$ & $\begin{array}{l}\text { Gross } \\
\text { return }\end{array}$ & $\begin{array}{c}\text { Net } \\
\text { return }\end{array}$ & BCR \\
\hline BRRI dhan $40 \times$ PU & 766 & 1227 & 461 & 1.60 \\
\hline BRRI dhan $41 \times$ PU & 766 & 1187 & 421 & 1.55 \\
\hline BRRI dhan $53 \times$ PU & 766 & 841 & 75 & 1.10 \\
\hline BRRI dhan54 × PU & 766 & 1229 & 463 & 1.60 \\
\hline BRRI dhan $52 \times$ PU & 766 & 1183 & 417 & 1.54 \\
\hline BRRI dhan $40 \times$ LCC & 764 & 1172 & 408 & 1.53 \\
\hline BRRI dhan $41 \times$ LCC & 764 & 1170 & 406 & 1.53 \\
\hline BRRI dhan $53 \times$ LCC & 764 & 866 & 102 & 1.13 \\
\hline BRRI dhan $54 \times$ LCC & 764 & 1191 & 426 & 1.56 \\
\hline BRRI dhan52 × LCC & 764 & 1197 & 432 & 1.57 \\
\hline BRRI dhan $40 \times$ USG & 748 & 1610 & 862 & 2.15 \\
\hline BRRI dhan $41 \times$ USG & 748 & 1612 & 865 & 2.16 \\
\hline BRRI dhan $53 \times$ USG & 748 & 1054 & 307 & 1.41 \\
\hline BRRI dhan 54 × USG & 748 & 1328 & 581 & 1.78 \\
\hline BRRI dhan52 × USG & 748 & 1429 & 682 & 1.91 \\
\hline BRRI dhan $40 \times$ RCM & 771 & 1063 & 291 & 1.38 \\
\hline BRRI dhan $41 \times$ RCM & 771 & 916 & 145 & 1.19 \\
\hline BRRI dhan $53 \times$ RCM & 748 & 472 & -276 & 0.63 \\
\hline BRRI dhan $54 \times$ RCM & 771 & 1094 & 323 & 1.42 \\
\hline BRRI dhan $52 \times$ RCM & 771 & 871 & 100 & 1.13 \\
\hline
\end{tabular}

PU: Prilled urea, LCC: Leaf colour chart, USG: Urea super granule, RCM: Rice crop manager.
Table 12. Economic analyses (US $\$ \mathrm{ha}^{-1}$ ) of cost and return of $\mathrm{N}$ management with new salt tolerant varieties in onfarm studies at Debhat, Satkhira during T. Aman 2013.

\begin{tabular}{|c|c|c|c|c|}
\hline Treatment & $\begin{array}{c}\text { Cost of } \\
\text { cultivation }\end{array}$ & $\begin{array}{l}\text { Gross } \\
\text { return }\end{array}$ & $\begin{array}{l}\text { Net } \\
\text { return }\end{array}$ & BCR \\
\hline BRRI dhan $40 \times$ PU & 749 & 1437 & 687 & 1.92 \\
\hline BRRI dhan $41 \times$ PU & 749 & 1436 & 687 & 1.92 \\
\hline BRRI dhan $53 \times$ PU & 749 & 1452 & 703 & 1.94 \\
\hline BRRI dhan $54 \times$ PU & 749 & 1415 & 665 & 1.89 \\
\hline BRRI dhan $52 \times$ PU & 749 & 1373 & 623 & 1.83 \\
\hline BRRI dhan $40 \times$ LCC & 760 & 1348 & 588 & 1.77 \\
\hline BRRI dhan $41 \times$ LCC & 760 & 1520 & 760 & 2.00 \\
\hline BRRI dhan $53 \times$ LCC & 760 & 1269 & 509 & 1.67 \\
\hline BRRI dhan54 × LCC & 760 & 849 & 90 & 1.12 \\
\hline BRRI dhan $52 \times$ LCC & 760 & 849 & 89 & 1.12 \\
\hline BRRI dhan $40 \times$ USG & 731 & 923 & 192 & 1.26 \\
\hline BRRI dhan 41 × USG & 731 & 725 & -6 & 0.99 \\
\hline BRRI dhan 53 × USG & 731 & 1424 & 693 & 1.95 \\
\hline BRRI dhan54 × USG & 731 & 1450 & 719 & 1.98 \\
\hline BRRI dhan52 × USG & 731 & 1467 & 736 & 2.01 \\
\hline BRRI dhan $40 \times$ RCM & 761 & 1422 & 661 & 1.87 \\
\hline BRRI dhan $41 \times$ RCM & 761 & 1420 & 659 & 1.87 \\
\hline BRRI dhan $53 \times$ RCM & 739 & 1298 & 560 & 1.76 \\
\hline BRRI dhan $54 \times$ RCM & 761 & 1511 & 750 & 1.99 \\
\hline BRRI dhan 52 × RCM & 761 & 1333 & 572 & 1.75 \\
\hline
\end{tabular}

PU: Prilled urea, LCC: Leaf colour chart, USG: Urea super granule, NM: Nutrient manager.

1992). Moreover, a BCR at least above 1.5 has been considered economically viable for an agricultural enterprise (Makarim et al., 2002). Thus, the calculated BCR, (Table 10) indicate that all tested treatments except BRRI dhan $54 \times$ LCC and BRRI dhan $53 \times$ LCC were economically viable. The actual net returns showed that some treatments were much more profitable than the others. In this respects, treatment BRRI dhan 54 $\times$ USG showed the higher net return of US\$ 552 ha $^{-1}$ in 2012 at Patuakhali. In Patuakhali during 2013, the higher benefit were observed in the treatments BRRI dhan $40 \times$ USG (2.15) and BRRI dhan $41 \times$ USG (2.16) and lower benefits were observed in the treatments BRRI dhan53 $\times$ prilled urea (1.10), BRRI dhan53 $\times$ LCC (1.13), BRRI dhan53 $\times$ nutrient manager (0.63), BRRI dhan $41 \times$ nutrient manager (1.19) and BRRI dhan $54 \times$ nutrient manager (1.13). In Satkhira, the higher benefits were observed in the treatments of BRRI dhan52 × USG (2.01), BRRI dhan $41 \times$ LCC (2.00). The lower benefits 
were found with the treatments of BRRI dhan41 $\times$ USG (0.99), BRRI dhan54 × LCC (1.12) and BRRI dhan52 $\times$ LCC (1.12) treatments. The experimental results clearly indicate that the application of USG gave more return than PU, LCC, and nutrient manager.

\section{CONCLUSION}

This study showed that nitrogen application through USG enhanced the growth, yield and yield attributes of rice as well as nitrogen uptake in both grain and straw. Among all the tested varieties, BRRI dhan40, BRRI dhan41 and BRRI dhan54 was better in both the locations. USG application was performed better in both the location and year. Rice crop manager needs to be updated for saline ecosystem. Improving nitrogen fertilization in coastal saline rice culture has potential to increase grain yield of saline tolerant rice. Such a cost effective and promising technology for the stress tolerant rice varieties can enhance the yield potential as well as upgrade the livelihood of the poor farmers in the study regions.

\section{ACKNOWLEDGEMENTS}

Authors are grateful to the International Rice Research Institute(IRRI), Los Baños, Philippines for providing financial and technical support through European Commission-International Fund for Agricultural Development (ECIFAD) funded project "Improved rice crop management for raising productivity in the submergence prone and salt affected rainfed lowlands in South Asia".

\section{REFERENCE}

AIS (Agricultural Information Service). (2015). Krishi Diary (In Bangla). Agril. Inform. Ser. Khamarbari, Farmgate, Dhaka, Bangladesh. p.17.

Aslam, M R H Qureshi, T Masood and R Ahmad. 1989. Yield and quality of maize fodder as influenced by nitrogen fertilizers in saline soil. Pakistan Journal of Soil Science 4: 5-9.
Bailey-Serres, J, TFukao, P C Ronald, A M Ismail, S Heuer and D J Mackill. 2010. Submergence tolerant rice: SUB1's journey from landrace to modern cultivar. Rice 3: 138-147.

Bremner, J M and C S Mulvaney. 1982. Total nitrogen. In: A L Page, $R$ H Miller and D RKeeny (Eds.), Methods of Soil Analysis. American Society of Agronomy and Soil Science Society of America, Madison, pp. 1119-1123.

BRKB (Bangladesh Rice Knowledge Bank). 2017. http:// knowledgebank-brri.org/Rice_Production_ Training_Manual/Day_1/Module_2/Aman/ Factsheet51-BRRI dhan54.pdf

CCC, 2009. Adaptive crop agriculture including innovative farming practices in the coastal zone of Bangladesh. Climate Change Cell, DoE, MoEF, Component 4b, CDMP, MoFDM. Dhaka: Bangladesh.

Fageria, N K, and V CBaligar. 2005. Enhancing nitrogen use efficiency in crop plants. Advances in Agronomy 88: 97-185.

Fageria, N K, N A Slaton and V CBaligar. 2003. Nutrient management for improving lowland rice productivity and sustainability. Advances in Agronomy 80: 63-152.

Fageria, N K and M P Barbosa Filho. 2001. Nitrogen use efficiency in lowland rice genotypes. Communications in Soil Science and Plant Analysis 32: 2079-2090.

Gomez, K A. 1972. Techniques for Field Experiments with Rice. IRRI, Los Banos, Philippines.

Gomez, K A and A A Gomez. 1984. Statistical Procedures for Agricultural Research, $2^{\text {nd }}$ edition. A Wiley-InterScience Publication, New York.

Haque, S A. 2006. Salinity problems and crop production in coastal regions of Bangladesh. Pakistan Journal of Botany 38: 1359-1365.

Islam, M S, K M Rahman, M M Rahman, M T Islam and M M Mashraf. 2011. Effect of salinity stress on growth and yield attributes in transplanted Aman rice genotypes. Journal of Agroforestry and Environment 5: 67-70.

Kabir, M H, N M Talukder, M J Uddin, H Mahmud and B K Biswas. 2011. Total nutrient uptake by grain plus straw and economic of fertilizer use of rice mutation STL-655 grown under Boro season in saline area. Journal of Environmental Science and Natural Resources 4: 83-87.

Karim, Z, S G Hussain and M Ahmed. 1990. Salinity problem and crop intensification in the coastal region of Bangladesh. BARC Soil Publication 33, pp. 63.

Lin, H X, S Yanagihara, J Y Zhuang, T Senboku, K L Zheng and S Yashima. 1998. Identification of QTL for salt tolerance in rice via molecular markers. Chinese Journal of Rice Science 12: 72-78. 
Mackill, D J, A M Ismail, U S Singh, R V Labios, T R Paris. 2012. Development and rapid adoption of submergence-tolerant (Sub1) rice varieties. Advances in Agronomy 115: 303-356.

Saleque, M A, U A Naher, N N Choudhury and A T M S Hossain. 2004. Variety specific nitrogen fertilizer recommendation for lowland rice. Communications in Soil Science and Plant Analysis 35: 1891-1903.

Sharma, N M R A Sarker, M A Rahman and M R Islam. 2013. Varietal evaluation of rice for improving productivity in southern Bangladesh. International Journal of Bioresearch 15: 7-13.

Singh, S D J Mackill, A M Ismail. 2009. Responses of SUB1 rice introgression lines to submergence in the field: yield and grain quality. Field Crops Research 113: 12-23.

Uddin, M S, M S I Khan, M M R Talukdar, M I Hossain and M H Ullah. 2011. Climate change and salinity in Bangladesh: constraints and management strategy for crop production. Rajshahi University Journal of environmental science 1: 13-20. 
